\title{
A Study on Emotional Literacy Scale Development ${ }^{*}$
}

\author{
Müge Akbağ ${ }^{1}$, Seval Eminoğlu Küçüktepe ${ }^{1}$, Esra Eminoğlu Özmercan ${ }^{2}$ \\ ${ }^{1}$ Marmara University, İstanbul, Turkey \\ ${ }^{2}$ Ministry of National Education, İstanbul, Turkey \\ Correspondence: Müge Akbağ, Atatürk Education Faculty, Marmara University, Kadıköy, İstanbul, Turkey.
}

$\begin{array}{lcc}\text { Received: February 1, } 2016 & \text { Accepted: February 18, } 2016 \quad \text { Online Published: February 27, } 2016 \\ \text { doi:10.11114/jets.v4i5.1419 } & \text { URL: http://dx.doi.org/10.11114/jets.v4i5.1419 }\end{array}$

\begin{abstract}
Emotional literacy is described as being aware of our own feelings in order to improve our personal power and life quality as well as people's life quality around us. In this study, the aim is to develop a Likert scale which measures people's emotional literacy in order to be used both in descriptive and experimental researches. Related literature was reviewed in accordance with this aim. Composition study was conducted and assessed with a group of experts in the field of psychological counseling $(n=25)$ regarding emotional literacy. Initial form which consists of 52 items were administered to 272 university students who were receiving education from different faculties in a university located at the west of Turkey. Afterwards, the final form which contains 34 items was applied to 345 university students. According to the results of explanatory and confirmatory factor analysis, the scale has five dimensions with 34 items. The Cronbach Alpha Coefficient is 0.80 ; test-retest validity which was repeated twice in 15 days' time with 45 students has been calculated as 0.89 . In conclusion, a reliable and valid scale which can be used to measure people's emotional literacy was developed.
\end{abstract}

Keywords: emotional literacy, scale development, reliability and validity

\section{Introduction}

\subsection{Problem}

Emotional literacy concept which was first mentioned in literature in 1970s by Claude Steiner (2003) who was a transactional analysis approach theoretician involves understanding, controlling and managing emotions. Steiner (2003) states that being a literate on the basis of emotions means to recognize our emotions in a way that we can benefit from it by improving our self-power and life quality as well as people's life quality around us. Steiner (1996, 2003), who did extensive researches regarding emotional literacy education, claims that emotional literacy involves five dimensions, arising from the emotion love, which are "being aware of one's own emotions, being able to empathize sincerely, knowing how to manage emotions, being able to restore emotional damage and being able to develop emotional interaction."

Despite the fact that emotional literacy is often used as a synonym to emotional intelligence; researchers make a statement emphasizing the differences between these concepts. Bocchino (1999) mentions that emotional intelligence is a potential arising from birth; however, emotional literacy is a skill that perceives and controls the affective processes that are developed after birth. Weare (2004), on the other hand, proposes using the emotional literacy concept would be more appropriate as it is quite contradictive to use intelligence word because it suggests that social and emotional capacity are structured at birth and, therefore, cannot be taught. He defines emotional intelligence as "...the skill to be able recognize and understand our self and other people's emotional conditions and to use this recognition in an efficient way..." Likewise, Sharp (2001) too advocates that the reason why emotional literacy is more preferable is because emotional literacy is more dynamic and mobile than emotional intelligence; therefore, it refers to a more teachable concept than emotional intelligence.

Literature reveals that there exist psychoeducational programs aiming to develop emotional literacy (Weare, 2004; Pearson \& Wilson, 2008) mainly based on emotional wellbeing and psychological resilience and they are widely used.

\footnotetext{
${ }^{*}$ An earlier version of this paper was presented at the II. Eurasian Educational Research Congress that took place at Hacettepe University, Ankara, Turkey, on June 8-10, 2015.
} 
Matsumoto (2012) noted that programs to be prepared concerning emotional literacy have a positive impact on the prevention of children and adolescents from dropping school. Another group of researchers emphasize that emotional literacy skills influence students' academic skills, friend relationships, mental health, social skills, forming good attitudes towards school, self-concept etc. positively (Antidote, 2003; Kandemir \& Dündar, 2008). Furthermore, there are some other researches focusing on adults rather than children or adolescents arguing that emotional literacy is connected with coping behavior, self-efficacy, general and emotional wellbeing (Chan, 2008; Adeyemo, 2007; Carmeli, Yitzhak - Halevy, \& Weisberg, 2009). It can be concluded that besides emotional literacy plays a key role in order to avoid mental health problems (Killick, 2006) it is also a significant factor to build and maintain a healthy interpersonal communication. Consequently, it can be drawn that studies regarding emotional literacy have an outstanding position in terms of preventive and protective psychological counseling and guidance services.

Measuring emotional literacy correctly is an important part of the process. It was observed that in literature, emotional intelligence scales were often used in order to identify the emotional literacy levels, to investigate the relations between emotional literacy and various psychological variables and also to test the efficiency of psychoeducational programs aiming to enhance emotional literacy (e.g.; Bar-On Emotional Intelligence Quotient Inventory, Mayer Slovey Caruso Emotional Intelligence Scale) while scales measuring emotional literacy were happened to be quite limited. So as to assess emotional literacy, some researchers use checklists (Mann, 2014) while some prefer developing a scale. Suhaily and Riah (2004) choose to develop a scale whose main goal is to measure middle-school students' emotional literacy levels. This scale comprises of five sub-dimensions which are self-regulation, internal motivation, social skill, empathy and self-awareness (Cited by Kandemir \& Dündar, 2008). A recent study by Palanc1, Kandemir, Dündar and Özpolat (2014) presents another emotional literacy scale which has three sub-dimensions; self-regulation, emotional awareness and social skill. It can be noted that those scales are designed to be used in school environments for students and consists of items based on educational environment and learning processes. On the other hand, in this study, the aim is to develop a Likert scale which measures young adults' and adults' emotional literacy on the basis of the five fundamental skills suggestions (being aware of one's own emotions, being able to empathize sincerely, knowing how to manage emotions, being able to restore emotional damage and being able to develop emotional interaction) made by Steiner (2003) whose field of work is about developing emotional literacy in the lights of interpersonal relationships arising from love. This scale is considered to be useful for the field both for descriptive and experimental researches regarding emotional literacy.

\section{Method}

\subsection{Participants and Procedures}

As a very first step of scale development, literature regarding emotional literacy was studied in order to generate items. Afterwards, a composition study was held with a group of experts in the field of psychological counseling $(\mathrm{n}=25)$ in order to identify the must-have characteristics concerning emotional literacy. As a result of both of these studies, 58 items were generated in a way that items involved all dimensions of emotional literacy. Items that were generated were firstly presented to the experts in the field of psychological counseling $(n=7)$ to be analyzed in terms of content, clarity and expression similarities. After the intended changes were made in accordance with the experts' opinions, there left 52 statements; 34 of which presenting high tendency $(+)$ while 18 of which presenting low tendency (-).

Initial form was applied to 281 students who were receiving education in a state university at the Marmara Region in Turkey in 2014-2015 academic year. Nine students who failed to complete the initial form as asked were excluded from the research. This study, in conclusion, was administered with 272 students.

In an attempt to analyze data and form the final scale, item analysis based upon item scale correlation and mean differences between groups and explanatory factor analysis were conducted. Items considered to be qualified according to these three techniques results were selected to the final form.

Final form was applied to 358 students who were receiving education in a state university at the Marmara Region in Turkey in 2014-2015 academic year. Students who failed to complete the final form as asked $(n=3)$ and who could not meet the assumptions of confirmatory factor analysis $(n=10)$ were discarded from the research. This study was administered with 345 participants.

\section{Findings}

\subsection{Item Analysis Based upon Item Scale Correlation}

Table 1 shows correlation coefficients of item scores with total score of the scale. 
Table 1. Item Analysis Results Based Upon Item Scale Correlation

\begin{tabular}{lllllllllll}
\hline Items & $1^{*}$ & $2^{*}$ & $3^{*}$ & $4^{*}$ & $5^{*}$ & $6^{*}$ & $7^{*}$ & $8^{*}$ & $9^{*}$ & $10^{*}$ \\
$\mathrm{r}$ & 0.507 & 0.487 & 0.264 & 0.560 & 0.299 & 0.462 & 0.428 & 0.330 & 0.478 & 0.520 \\
\hline Items & $11^{*}$ & $12^{*}$ & $13^{*}$ & $14^{*}$ & $15^{*}$ & $16^{*}$ & $17^{*}$ & $18^{*}$ & $19^{*}$ & $20^{*}$ \\
$\mathrm{r}$ & 0.471 & 0.484 & 0.554 & 0.532 & 0.495 & 0.340 & 0.389 & 0.485 & 0.413 & 0.301 \\
\hline Items & $21^{*}$ & $22^{*}$ & $23^{*}$ & $24^{*}$ & $25^{* *}$ & $26^{*}$ & $27^{*}$ & $28^{*}$ & $29^{*}$ & $30^{*}$ \\
$\mathrm{r}$ & 0.286 & 0.392 & 0.487 & 0.458 & 0.127 & 0.422 & 0.360 & 0.582 & 0.193 & 0.237 \\
\hline Items & $31^{*}$ & $32^{*}$ & $33^{*}$ & $34^{*}$ & $35^{*}$ & $36^{*}$ & $37^{*}$ & $38^{*}$ & $39^{*}$ & $40^{*}$ \\
$\mathrm{r}$ & 0.464 & 0.146 & 0.344 & 0.334 & 0.224 & 0.157 & 0.459 & 0.513 & 0.406 & 0.416 \\
\hline Items & $41^{*}$ & $42^{*}$ & $43^{*}$ & $44^{*}$ & $45^{*}$ & $46^{*}$ & $47^{*}$ & $48^{*}$ & $49^{*}$ & $50^{*}$ \\
$\mathrm{r}$ & 0.246 & 0.400 & 0.463 & 0.424 & 0.411 & 0.457 & 0.388 & 0.391 & 0.460 & 0.467 \\
\hline Items & $51^{*}$ & $52^{*}$ & & & & & & & & \\
$\mathrm{r}$ & 0.303 & 0.318 & & & & & & & &
\end{tabular}

It can be interpreted from the Table 1 that all items in the scale measure the same construct as overall scale does. Hence, items which were utilized in the initial form are qualified enough to be a part of the final scale.

\subsection{Item Analysis Based upon Mean Differences between Groups}

Scores which were obtained from students' answer were ranked in a descending order. 73 students who had the lowest scores were grouped as the lower and 73 who had the highest scores were assigned to the higher group. Afterwards, the mean score difference for each item between the lower and the higher groups were analyzed with independent samples t-test. The results are as shown in Table 2.

Table 2. Item Analysis Results Based Upon Mean Differences between Groups

\begin{tabular}{lllllllllll}
\hline Items & $1^{*}$ & $2^{*}$ & $3^{*}$ & $4^{*}$ & $5^{*}$ & $6^{*}$ & $7^{*}$ & $8^{*}$ & $9^{*}$ & $10^{*}$ \\
$\mathrm{t}$ & 53.655 & 42.228 & 33.908 & 34.294 & 43.624 & 53.129 & 23.976 & 25.783 & 48.739 & 34.913 \\
\hline Items & $11^{*}$ & $12^{*}$ & $13^{*}$ & $14^{*}$ & $15^{*}$ & $16^{*}$ & $17^{*}$ & $18^{*}$ & $19^{*}$ & $20^{*}$ \\
$\mathrm{t}$ & 43.102 & 45.025 & 41.828 & 62.138 & 49.350 & 52.881 & 64.750 & 45.694 & 24.667 & 49.040 \\
\hline $\mathrm{Items}$ & $21^{*}$ & $22^{*}$ & $23^{*}$ & $24^{*}$ & $25^{*}$ & $26^{*}$ & $27^{*}$ & $28^{*}$ & $29^{*}$ & $30^{*}$ \\
$\mathrm{t}$ & 24.309 & 33.344 & 45.705 & 58.601 & 67.772 & 47.915 & 39.205 & 46.757 & 48.917 & 34.759 \\
\hline Items & $31^{*}$ & $32^{*}$ & $33^{*}$ & $34^{*}$ & $35^{*}$ & $36^{*}$ & $37^{*}$ & $38^{*}$ & $39^{*}$ & $40^{*}$ \\
$\mathrm{t}$ & 61.921 & 34.847 & 28.097 & 49.395 & 46.300 & 40.061 & 48.198 & 37.216 & 34.674 & 41.296 \\
\hline Items & $41^{*}$ & $42^{*}$ & $43^{*}$ & $44^{*}$ & $45^{*}$ & $46^{*}$ & $47^{*}$ & $48^{*}$ & $49^{*}$ & $50^{*}$ \\
$\mathrm{t}$ & 24.627 & 26.536 & 64.804 & 50.165 & 27.933 & 63.275 & 43.958 & 39.215 & 40.756 & 54.727 \\
\hline Items & $51^{*}$ & $52^{*}$ & & & & & & & & \\
$\mathrm{t}$ & 47.348 & 43.741 & & & & & & & &
\end{tabular}

Table 2 shows that each item on the scale is sufficient enough to discriminate between people who have the feature which is aimed to be measured by this item and who have not. Therefore, items which were utilized in the initial form are qualified enough to be a part of the final scale.

\subsection{Factor Analysis}

In order to decide if the data gathered from the initial form was appropriate for factor analysis, Kaiser-Meyer-Olkin (KMO) and Bartlett's Test of Sphericity were conducted. Results are as shown in Table 3. 
Table 3. Kaiser-Meyer-Olkin (KMO) and Barlett's Test of Sphericity Results

\begin{tabular}{|c|c|c|}
\hline \multirow[t]{2}{*}{ Kaiser-Meyer-Olkin Measure of Sampling Adequacy } & \multicolumn{2}{|c|}{0.771} \\
\hline & $\mathrm{X}^{2}$ & 3228.499 \\
\hline Bartlett's Test of Sphericity & $\mathrm{df}$ & 595 \\
\hline & $\mathrm{p}$ & 0.000 \\
\hline
\end{tabular}

As shown in Table 3, KMO fitness index was calculated as 0.771. This index is greater than the accepted critical value which is 0.70 (Şencan, 2005; Tavşancil, 2006). Barlett's test of sphericity was found to be 3228.499 which is statistically significant at 0.000 level. It can be concluded that data obtained from initial form can be employed to the factor analysis.

\subsubsection{Explanatory Factor Analysis (EFA)}

Factor analysis was conducted with 52 item scale in order to identify the fundamental factors related to the construct. First, it was determined that which items placed themselves under which factors. Later, items that had factor loading less than 0.32, that had factor loading greater than 0.32 under more than one dimension and that factor loading differences was less than 0.1 were discarded from the scale (Tabachnick \&Fidel, 2001). Total 17 items, at the end, were excluded from the scale. The final form constituted of 35 items. Factor analysis results were given in Table 4.

Table 4. Factor Analysis Results

\begin{tabular}{lccccccccc}
\hline \multirow{2}{*}{ Factors } & \multicolumn{3}{c}{ Eigenvalues } & \multicolumn{3}{c}{ Values Before Rotation } & \multicolumn{3}{c}{ Values After Rotation } \\
\hline & Total & $\begin{array}{c}\text { Variance } \\
\text { \% Cumulative }\end{array}$ & Total & Variance & Cumulative & Total & Variance & Cumulative \\
& & $\%$ & $\%$ & & $\%$ & $\%$ & & $\%$ & $\%$ \\
\cline { 2 - 9 } 1 & 6.399 & 18.284 & 18.284 & 6.399 & 18.284 & 18.284 & 4.576 & 13.073 & 13.073 \\
2 & 2.961 & 8.459 & 26.743 & 2.961 & 8.459 & 26.743 & 3.759 & 10.740 & 23.813 \\
3 & 2.719 & 7.768 & 34.511 & 2.719 & 7.768 & 34.511 & 2.704 & 7.726 & 31.539 \\
4 & 2.036 & 5.818 & 40.329 & 2.036 & 5.818 & 40.329 & 2.639 & 7.539 & 39.078 \\
5 & 1.771 & 5.061 & 45.391 & 1.771 & 5.061 & 45.391 & 2.209 & 6.313 & 45.391 \\
\hline
\end{tabular}

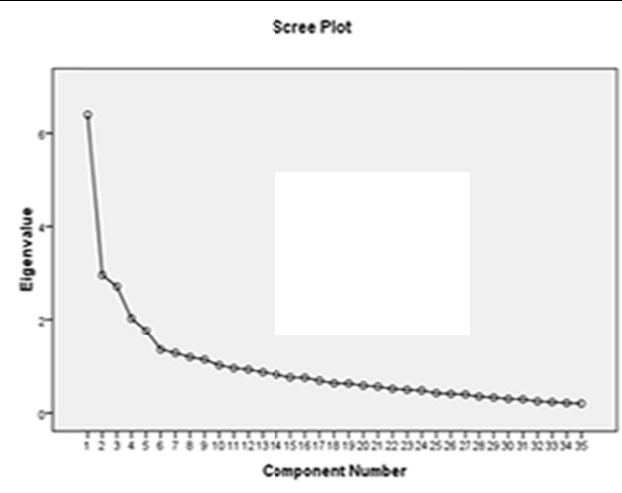

Figure 1. Scree plot

When scree plot is investigated, it is clear that the scale has five dimensions. First factor was named as 'emotional awareness' (eg. "I can easily feel other people's emotions", "I am aware of how my emotions affect other people"); the second factor was named as 'social competence' (e.g. "I deliver positive messages (admiration, compliment, approval etc.) to people.", "It is hard for me to apologize when I do wrong."); the third factor was named as "understanding emotions' (e.g. "I recognize the differences between emotions like love, hate, joy, shame etc.", "Even though I realize the physical symptoms, I am often unaware of the feelings that causes them"); the forth factor was named as 'emotional-self efficacy' (e.g. "I fear that I may be ridiculous, silly etc. when I am emotional.", "I am quite cautious to express my emotions because of the disappointment I have experienced."; the fifth factor was named as 'regulating 
emotions' (e.g. "I do not hesitate to show my reaction when I am angry.", "Working under extensive pressure and stress does not affect my productivity (performance) thanks to my being nonchalant"). Table 5 shows the dimension and factor loadings of items.

Table 5. Dimensions and Factor Loadings of Items

\begin{tabular}{|c|c|c|c|c|c|}
\hline \multirow[b]{2}{*}{ Items } & \multicolumn{5}{|c|}{ Sub-dimensions } \\
\hline & 1 & 2 & 3 & 4 & 5 \\
\hline i1 & 0.791 & & & & \\
\hline i2 & 0.769 & & & & \\
\hline i6 & 0.733 & & & & \\
\hline i18 & 0.663 & & & & \\
\hline $\mathrm{i} 21$ & 0.573 & & & & \\
\hline $\mathrm{i} 28$ & 0.515 & & & & \\
\hline i34 & 0.503 & & & & \\
\hline i23 & 0.493 & & & & \\
\hline i15 & 0.437 & & & & \\
\hline i29 & & 0.722 & & & \\
\hline i7 & & 0.694 & & & \\
\hline i12 & & 0.630 & & & \\
\hline$i 35$ & & 0.623 & & & \\
\hline i14 & & 0.581 & & & \\
\hline i19 & & 0.533 & & & \\
\hline $\mathrm{i} 22$ & & 0.517 & & & \\
\hline i24 & & 0.503 & & & \\
\hline $\mathrm{i} 33$ & & 0.417 & & & \\
\hline i2 & & 0.402 & & & \\
\hline i8 & & & 0.806 & & \\
\hline $\mathrm{i} 32$ & & & 0.695 & & \\
\hline i13 & & & 0.583 & & \\
\hline i25 & & & 0.482 & & \\
\hline i3 & & & 0.347 & & \\
\hline i16 & & & & 0.700 & \\
\hline i9 & & & & 0.659 & \\
\hline i4 & & & & 0.641 & \\
\hline i20 & & & & 0.520 & \\
\hline i31 & & & & 0.479 & \\
\hline i26 & & & & 0.423 & \\
\hline $\mathrm{i} 10$ & & & & & 0.740 \\
\hline i27 & & & & & 0.635 \\
\hline i5 & & & & & 0.603 \\
\hline i17 & & & & & 0.481 \\
\hline i30 & & & & & 0.344 \\
\hline
\end{tabular}

3.3.2 Confirmatory Factor Analysis (CFA)

Confirmatory factor analysis was conducted with LISREL 8.37 package program. Confirmatory factor analysis results reveal that all the items are statistically significant at 0.05 level meaning that all items (observed variables) are representing their latent variable except from item 10 under the fifth dimension. Critical value (1.96) is greater than $t$ value calculated for item 10. Therefore, it is considered that this item failed to present its latent variable, as a result, was discarded from the model. Items $(\mathrm{n}=34)$ factored under five dimensions were re-analyzed.

Fit indexes calculated in this study are as shown in Table 6. 
Table 6. Emotional Literacy Scale Measurement Model Fit Indexes

Fit Index Statistics

Degrees of Freedom (df)

Chi-Square $\left(\mathrm{X}^{2}\right)$

$\mathrm{X}^{2} / \mathrm{df}$

Root Mean Square Error of Approximation (RMSEA)

Comparative Fit Index (CFI)

Goodness of Fit Index (GFI)

Adjusted Goodness of Fit Index (AGFI)
Values

1043.73

0.052

0.89

0.85

0.83

The ratio of chi square with degree of freedom is $1043.73 / 542=1.93$. This value proves that there is excellent fit (Tabachnick \& Fidel, 2001) between the original variable matrix and the suggested matrix. RMSEA value which was calculated as 0.052 shows good fit for the measurement model (Hu \& Bentler, 1999). However, CFI fit index which was 0.89 suggests a weak but yet non-negligible fit as the value is smaller than the critical value. GFI and AGFI fit indexes are respectively 0.85 and 0.83 . Even though GFI and AGFI values are below the acceptable interval, GFI being greater than 0.85 and AGFI being greater than 0.80 propose that fit indexes are at the lower limits of model acceptance (Anderson \& Gerbing, 1984; Cole, 1987; Marsh, Balla \& McDonald, 1988 cited by Duyan \& Gelbal, 2008; Schermelleh-Engel, Moosbrugger \& Müller, 2003).

When the obtained values were compared with expected critical values, it is clear that values obtained from this study are in acceptable interval. Based on this result, it can be concluded that each factor presents the statements.

\subsection{Reliability of the Scale}

Cronbach alpha reliability coefficient of the scale for the first factor is 0.75 ; for the second factor is 0.73 ; for the third factor is 0.71 ; for the fourth factor is 0.71 and for the fifth factor is 0.72 . Reliability coefficient for overall scale was calculated as 0.80 . In order to figure out the test-retest validity, final form was administered to 45 people twice in 15 days' time. The correlation between the administrations were calculated. According to the results, the correlation for the first factor is 0.71 ; for the second factor is 0.76 ; for the third factor is 0.73 ; for the fourth factor is 0.75 and for the fifth factor is 0.78 . Validity coefficient for overall scale was determined as 0.89 . This value acknowledges that the scale produces consistent results. Those findings support that the scale has a satisfactory level of reliability.

\section{Discussion and Conclusion}

The scale which was developed in this study and named as Emotional Literacy Scale contains "emotional awareness", "social competence", "understanding emotions", "emotional self-efficacy" and "regulating emotions" sub-dimensions and 34 items. In the lights of the obtained findings, it can be concluded that Emotional Literacy Scale is a valid and reliable measurement tool. According to the explanatory and confirmatory factor analysis results, Emotional Literacy Scale is a multi-dimensional scale. This situation is consistent with the theoretical descriptions of emotional literacy in literature and also is similar with the existing scales presenting multidimensional constructs (Steiner, 2003; Mann, 2014; Palanci et al., 2014).

This scale can be used for the researches which are designed for young adults and adults to investigate the relationship between emotional literacy and various variables and also to test the psychoeducational programs which are developed to enhance emotional literacy. As it is developed in order to measure the young adults' and adults' emotional literacy skills, it is also suggested that appropriate versions of the scale for different age groups should be developed.

\section{References}

Adeyemo, D. A. (2007). Moderating influence of emotional intelligence on the link between academic self-efficacy and achievement of university students. Psychology Developing Societies, 19(2), 199-213. http://dx.doi: 10.1177/097133360701900204

Antidote, J. P. (2003). The emotional literacy handbook: Promoting whole-school strategies. London: David Fulton Publishers.

Bocchino, R. (1999). Emotional literacy: To be a different kind of smart. Thousand Oaks, CA: Sage Publications.

Carmeli, A., Yitzhak - Halevy, M., \& Weisberg, J. (2009). The relationship between emotional intelligence and psychological wellbeing, Journal of Managerial Psychology, 24(1), 66-78. 
http://dx.doi.org/10.1108/02683940910922546

Chan, D. W. (2008). Emotional intelligence, self - efficacy, and coping among Chinese prospective and in - service teachers in Hong Kong. Educational Psychology: An International Journal of Experimental Educational Psychology, 28(4), 397-408. http://dx.doi:10.1080/01443410701668372

Duyan, V., \& Gelbal, S. (2008). Barnett çocuk sevme ölçeğini Türkçeye uyarlama çalışması. [The adaptation study of Barnett liking of children scale to Turkish]. Eğitim ve Bilim, 148(33), 40-48.

Hu, L. T., \& Bentler, P. M. (1999). Cutoff criteria for fit indexes in covariance structure analysis: conventional criteria versus new alternatives. Structural Equation Modeling: A Multidisciplinary Journal 6(1), 1-55. http://dx.doi:10.1080/10705519909540118

Kandemir, M., \& Dündar, H. (2008). Duygusal okuryazarlık ve duygusal okuryazar öğrenme ortamları [Emotional literacy and emotionally literate learning environments]. Sakarya Üniversitesi Eğitim Fakültesi Dergisi, (16), 83-90.

Killick, S. (2006). Emotional literacy at the heart of the school ethos. Thousand Oaks, CA: Sage Publications.

Mann, D. (2014). A mixed methods evaluation of the emotional literacy support assistant (ELSA) project (Unpublished doctoral dissertation). University of Nottingham, United Kingdom.

Matsumoto, R. I. M. (2012). Emotional litteracy in Schools, dropout prevention in Latino middle school students using emotional literacy. A research paper presented to the faculty of Adler graduate school. In partial fulfillment of the requirements for the degree of master of arts in school counseling.

Palancı, M., Kandemir, M., Dündar, H., \& Özpolat, A. R. (2014). Duygusal okuryazarlık ölçeğinin geçerlilik ve güvenirlik çalışması. [Validity and reliability study of Emotional Literacy Scale]. International Journal of Human Sciences, 11(1), 481-494. http://dx.doi: 10.14687/ijhs.v11i1.2806

Pearson, M., \& Wilson, H. (2008). Using expressive counselling tools to enhance emotional literacy, emotional wellbeing and resilience improving therapeutic outcomes with expressive therapies. Counselling, Psychotherapy, and Health, 4(1), 1-19.

Schermelleh-Engel, K., Moosbrugger, H., \& Müller, H. (2003). Evaluating the fit of structural equation models: tests of significance and descriptive goodness-of-fit measures. Methods of Psychological Research Online, 8(2), 23-74.

Şencan, H. (2005). Sosyal ve davranışsal ölçümlerde güvenirlik ve geçerlik. Ankara: Seçkin Yayıncılık.

Sharp, P. (2001). Nurturing emotional literacy. David Fulton Publishers.

Steiner, C. M. (1996). Emotional literacy training: The application of transactional analysis to the study of emotions. Transactional Analysis Journal, 26(1), 31-39. http://dx.doi: 10.1177/036215379602600107

Steiner, C. M. (2003). Emotional literacy: Intelligence with a heart. Fawnskin, CA: Personhood Press.

Tabachnick, B. G., \& Fidel, L. S. (2001). Using multivariate statistics. (4th ed.). MA: Allyn \& Bacon, Inc.

Tavşancıl, E. (2006). Tutumların ölçülmesi ve SPSS ile veri analizi. (Üçüncü baskı). Ankara: Nobel Yayın Dağıtım.

Weare, K. (2004). Developing the emotionally literate school. London: Sage Publications.

\section{$(\infty)) E Y$}

This work is licensed under a Creative Commons Attribution 3.0 License. 